\title{
レーザーオリジナル
}

\author{
軸モード間ビート法による内部鏡型 \\ He-Neレーザーの安定化 \\ 佐々木 彰 ${ }^{*}$. 岡田武彦 ${ }^{* *}$. 河合 淳 ${ }^{* * *}$. 青山尚之*
}

(1993年 2 月 9 日 受理)

\section{Frequency Stabilization of an Internal-Mirror He-Ne Laser using an Axial Mode Beat}

\author{
Akira SASAKI*, Takehiko OKADA**, Sunao KAWAI*** \\ and Hisayuki AOYAMA*
}

(Received February 9, 1993)

\begin{abstract}
The frequency of a commercially available internal-mirror He-Ne laser $(\lambda=633 \mathrm{~nm})$ was stabilized by using an axial-mode beat frequency. The beat-frequency conversion technique between the axial-beat frequency and the output signal of a frequency synthesizer was used for the laser frequency stabilization. The frequency stability of $4.5 \times 10^{-10}$ was estimated by means of the Allan variance analysis. The amplitude stability of this stabilized laser was estimated to be $0.21 \%$.
\end{abstract}

Key Words : Frequency stabilization, He-Ne laser, Internal-mirror He-Ne laser.

\section{1.はじめに}

内部鏡型He-Neレーザー $(\lambda=633 \mathrm{~nm})$ は, 可 視光であること, レーザービーム特性が良質で あること，低電力で作動することなどから基礎 的研究及びレーザー応用計測などに，現在にい たるまで広く利用されている。しかしながら， それを精密な測定に使用する場合, レーザーは 出力が数\%変動すること及び周波数が $10^{-6}$ のオー ダーで変動していることが問題となる。特に超
精密測定及び高精度レーザー干渉計を使用した 計測において，レーザー周波数変動が特に問題 となる。その場合, 周波数安定化されたレーザー

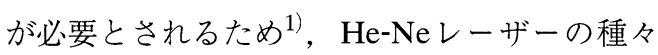
の安定化法が研究されてきている ${ }^{2-13)}$ 。

レーザー周波数の変動は, 主にレーザー管の 熱膨張及び収縮による光共振器長の変動に起因 している。内部鏡型He-Neレーザーにおいては 放電管とレーザー反射鏡が一体化されているた め, 反射鏡の間隔がレーザー管の温度上昇と共

* 静岡大学工学部 (₹432 浜松市城北3-5-1)

$* *$ 住友電気工業 $($ 株) (

***ブラザー工業(株) (テ467 名古屋市瑞穂区苗代町15-1)

* Faculty of Engineering, Shizuoka Univer-sity (Johoku, Hamamatsu 432)

* * Sumitomo Electric Industries, Ltd. (1 Taya-machi, Sakae-ku, Yokohama 244)

***Brother Industries, Ltd. (Nawashiro-chou, Mizuho-ku, Nagoya 467) 
に熱膨張し，軸モードが移動し，レーザー出力 や周波数が变動する。そこで, 光共振器の長さ を熱的に制御し，一定に保つことによってレー ザー周波数の安定化を行ってきた ${ }^{2-10)}$ 。安定化 は, レーザーの強度 ${ }^{3)}, \mathrm{Lamb}$ くぼみ2), あるい は, 内部鏡型He-Neレーザーの偏光状態を利用 し4，レーザーの共振器長が一定になるように 制御されている。これらの安定化法はレーザー 強度変化を利用しているため，レーザーの放電 電流変動による強度変動の影響, 光検出素子, 電流一電圧変換器, 増幅器, 制御回路及び基準 電圧の経年変化, またレーザー管及び上記電子 回路の温度変動の影響を受けやすい。

内部鏡型He-Neレーザーに横あるいは縦方向 に磁場を印加し，Zeemanビート周波数を検出 してレーザー周波数を制御する方法が開発され ている5)。この方法は, 交流信号を制御信号と して用いているため, レーザー計測への応用範 囲も広い。一般にこのビート周波数はレーザー 管により異なるが，1 MHz程度である。この周 波数を積極的に利用した種々の計測が行われて いる。しかし，ビート周波数が低いため，高速 計測への光源としては適していない。そこで, 光強度の变動や光学的及び電気的雑音の影響を 受けにくく，また高速変動現象も計測可能であ る方法が望まれている。その方法としてレーザー の軸モード間ビート周波数の変化を直接検出し, それを制御信号として用いた新しい安定化法が 必要とされている10)。本報告において，この軸 モード間ビート周波数を使用した安定化法の原 理, 安定化システム及び安定化の実験結果につ いて詳細を述べる。

\section{2. 安定化原理}

He-Neレーザーの出力特性曲線をFig. 1 (a)に 示す。2本の軸モードで発振しているレーザー の周波数と出力強度は, 罒に示すようにレーザー 管の熱膨張あるいは収縮により軸モードが移動 するため変動する。また, 各々の軸モードはレー ザー反射鏡の異方性のため, 互いに直交偏光し ている ${ }^{11)}$ 。各偏光方向をそれぞれ $\|$ 及びよで識
別すると出力強度は $I_{\|}$及び $I_{\perp}$ で表される。

一方, 観測される出力強度 $\left(I=I \|+I_{\perp}\right)$ は内 部鏡型レーザー管の長さが熱的に変動すると, 共振器の長さ $L$ 変動するため, 軸モードが移 動し, Fig. 1(b)に示すようになる。2本の軸モー ドの周波数を各々 $f_{1}$ 及び $f_{2}$ とすると, 軸モード 間のビート周波数は $f_{\mathrm{B}}=\left|f_{1}-f_{2}\right|$ と表される。 このビート周波数は, 偏光方向に対し, レーザー 共振器の $Q$ 值や屈折率の違いにより, Fig. 1 (c) に示すようにレーザー管の長さ変化に伴い変動 する ${ }^{12)}$ 。また，ビート周波数は軸モード間の相 互作用及び非線形性に依存する。強度比較を採 用した制御法では，基本的にこれらの周波数変 動は制御できない。そこで, 軸モード間ビート 周波数を誤差信号として，レーザー周波数の安

(a)

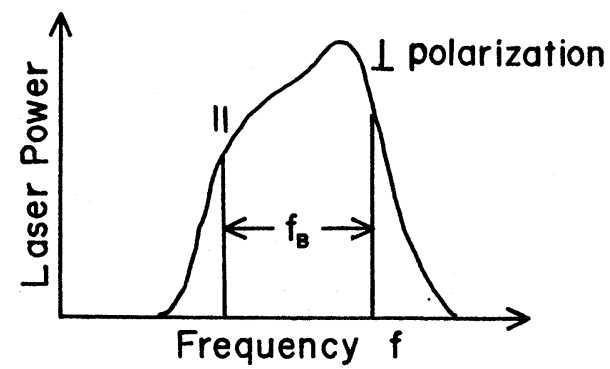

(b)

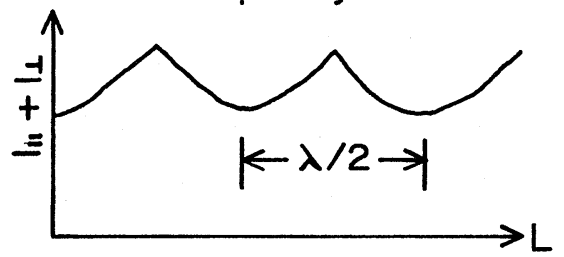

(c)

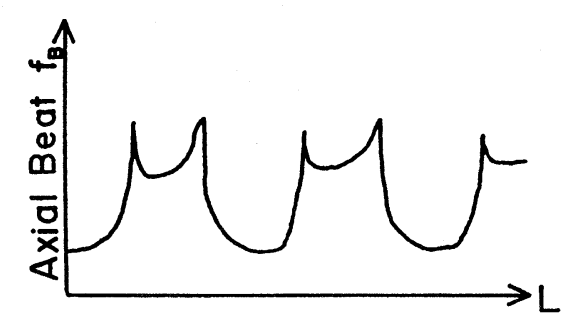

Fig. 1 Schematic representation of (a) a laser gain profile as a function of frequency ; (b) laser output power and (c) axial-beat frequency as a function of the laser cavity length $L$. $\lambda$ is the laser wavelength. 
定化を行った。

軸モードビートの周波数は高く制御信号として 適していないため, ビート信号 $\triangle f=\left|f_{\mathrm{B}}-f_{\mathrm{PLL}}\right|$ のように周波数変換して使用した。ここで $f_{\mathrm{PLL}}$ は, 基準周波数発振器に水晶発振子 $\left(1.4 \times 10^{-10}\right.$ $\left./{ }^{\circ} \mathrm{C}\right)$ を使用した周波数シンセサイザーの発振 周波数である。この $\Delta f$ を電圧信号に変換し, 熱的にレーザー管の長さを制御し, 安定化を行っ た。

\section{3. 実 験}

実験に使用したレーザー安定化のためのブロッ ク図をFig. 2に示す。また、レーザー管の周囲 の図をFig. 3に示す。内部鏡型 $\mathrm{He}-\mathrm{Ne}$ レーザー は, UNL-210R (ウシオ社, $30 \mathrm{~mm}$ 同軸構造) で, 軸モード間周波数が $650 \mathrm{MHz}$ (レーザー管長 230 $\mathrm{mm})$ であり，通常2ないし3本の軸モードで同 時発振する。放電電流の変動はレーザーの周波 数及び強度に影響を与えるため, 自作の高精度 定電流電源 ${ }^{13)}$ を使用した。この電源の最大放電 電流は $5 \mathrm{~mA} ゙$ でり, 電流安定度は土0.001\% 以下であった。定電流電源にレーザー管は，バ ラスト抵抗 $(50 \mathrm{k} \Omega)$ を介して接続した。

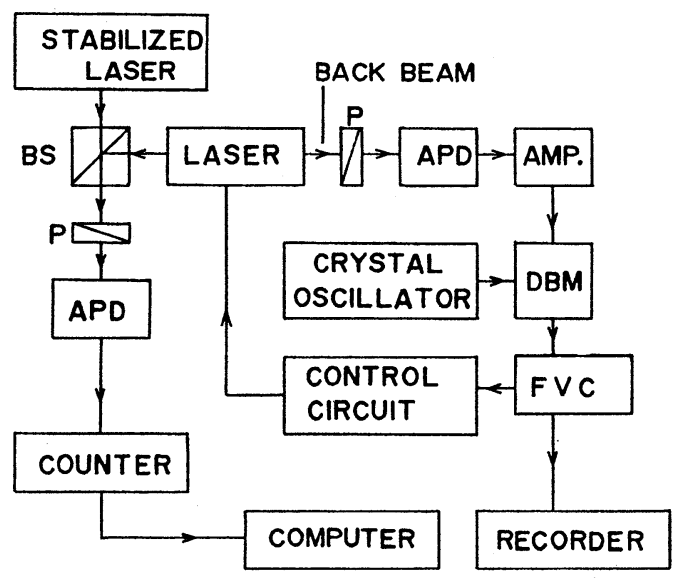

Fig. 2 Experimental arrangement for frequency stabilization : P, polarizer ; APD, silicone avalanche photodiode ; DBM, double balanced mixer ; FVC, frequency-voltage converter ; BS, beam splitter.
安定化状態にあるレーザー共振器長が变化し ない状態においてもレーザー回りの室温が変化 すると, レーザー管の熱膨張のため管径等が変 化し，レーザー管の封入気体圧力が変動する。 これが主原因で, レーザー周波数が約 $0.4 \mathrm{MHz} /{ }^{\circ} \mathrm{C}$ で変動するため ${ }^{2,14)}$ ，レーザー管を直径 $40 \mathrm{~mm}$ のアルミニウム管内にテフロンで固定し, その アルミニウム管の温度を制御した。アルミニウ ム管の外側に温度制御用のニクロム線ヒー夕を 電気的に絶縁して巻いた。ヒー夕線に電流を流 すと磁界が発生する。これらの効果を避けるた め, 2本のヒー夕線を平行に巻き, 各々の巻線 に逆方向の電流を流し, 磁界の発生を防止した。 これはレーザー管に磁界を印加した場合, Zeeman分離と軸磁界による周波数変動を防止 するためである。アルミニウム管は, 室温の変 動によりレーザー管の温度が変動するため, ガ ラス繊維で覆った。この状態で $30{ }^{\circ} \mathrm{C} に$ 温度制 御したとき,アルミニウム管内部の温度変動は $\pm 0.2^{\circ} \mathrm{C}$ であった。この温度変動は, レーザー 周波数変動に換算すると, $\pm 80 \mathrm{kHz}$ となり, 本研究では十分な性能であると考えられる。レー ザー周波数を安定化するため, レーザー管に MINCO社のフィルム・ヒータ $(360 \Omega)$ を両面 接着テープで固定し, 共振器長を熱的に制御し た。また,レーザー管後側ミラーの裏面からの 戻り光により安定度が低下することを防ぐため， エッジ状のガラス板をミラーの裏面に接着した。 制御信号として使用するビート周波数 $f_{\mathrm{B}}$ はレー ザー管の後側に出力されるビームから検出した。

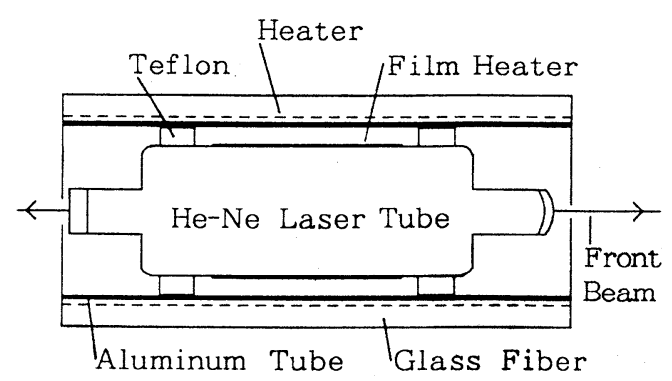

Fig. 3 Schematic representation of the laser tube circumference. 
そのため, 前方へのビームは, 計測等に有効に 使用できる。内部鏡型He-Neレーザーの隣り合 う軸モードは，レーザー反射鏡の異方性のため 互いに直交した方向に直線偏光している11)。そ こでモード間ビート周波数は, レーザー管の後 側に偏光子を $45^{\circ}$ の方位で設置し, シリコン・ アバランシェ・フォトダイオード (APD, 浜松 ホトニクス，S2382)によって検出した。この $\mathrm{APD}$ の出力信号は高周波増幅器により増幅さ れた。ビート周波数の変動は, 増幅器出力をス ペクトル・アナライザーに導き観測した。軸モー ドの発振特性は光スペクトル・アナライザーで 測定した。ダブル・バランスド・ミキサー(DBM) はビート周波数 $f_{\mathrm{B}}$ の周波数变換器として用いた。 $\mathrm{FVC}$ は $\triangle f$ 周波数一電圧変換器である。制御 信号は, FVCの出力信号と基準電圧 (高安定温 度補償型ツェナーダイオードLM399を使用)を 差動増幅器 (INA101HP) で比較し発生させた。 その信号でレーザー管に巻いたフィルム・ヒー 夕を加熱し、レーザー管長を熱的に制御した。 制御系の時定数及び利得は, 安定化系が最適制 御状態になるように選択した。加熱によりレー ザー管長を制御するため, 制御時にはレーザー 管長が収縮状態にあることが必要であり, 制御 前にフィルム・ヒータに電流を流し，レーザー 管長を十分に熱膨張させた。また，FVCの出力 をペンレコーダに接続し，レーザー管の熱膨張 の特性と熱膨張時の軸モードのビート周波数変 動の状況及び周波数安定化の状態を記録した。

本安定化法で安定化したレーザーの周波数安 定度評価のため, 他の安定化レーザー15) (ミツ トヨ LSI-50， $\lambda=632990937.4 \mathrm{fm}$ (沃素安定化 レーザーで校正済み波長)) とのビート周波数を 偏光素子を使用しAPDで検出し, 周波数カウ ンタで計数した。カウンタの計数結果をパーソ ナルコンピュータに取り込み, アラン分散 ${ }^{16)}$ で 安定度の評価を行った。

\section{4. 実験結果及び考察}

本研究で使用したレーザー管の点灯時からの 熱膨張特性を, 出力変動より見積もり ${ }^{3)}$, Fig. 4

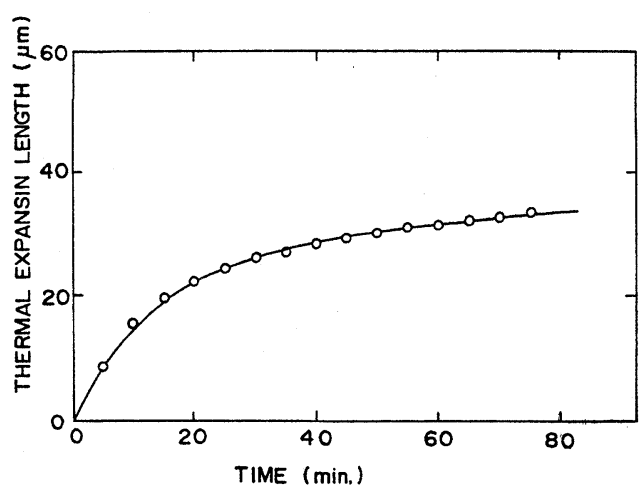

Fig. 4 Thermal expansion length of the laser tube as a function of time after start of discharge.

に示す。この図は,アルミニウム管の温度制御 をレーザー点灯時から行い, また制御用のフィ ルム・ヒータを加熱状態にした場合を示してい る。アルミニウム管の温度は約20分後に設定值 となり, 温度変動幅は $\pm 0.2^{\circ} \mathrm{C}$ であった。しか し, この状態でもレーザー管は多少線膨張状態 にある。

Fig. 5は, 熱膨張状態における軸モード間ビー 卜周波数変動の拡大図である。この図で示した ように軸モード間ビート周波数はレーザー管の 熱膨張と共に変動している。このビート周波数 の変動幅は $1.36 \mathrm{MHz}$ であった。この值は他の レーザーでほぼ同じ值である ${ }^{12)}$ 。光スペクトル

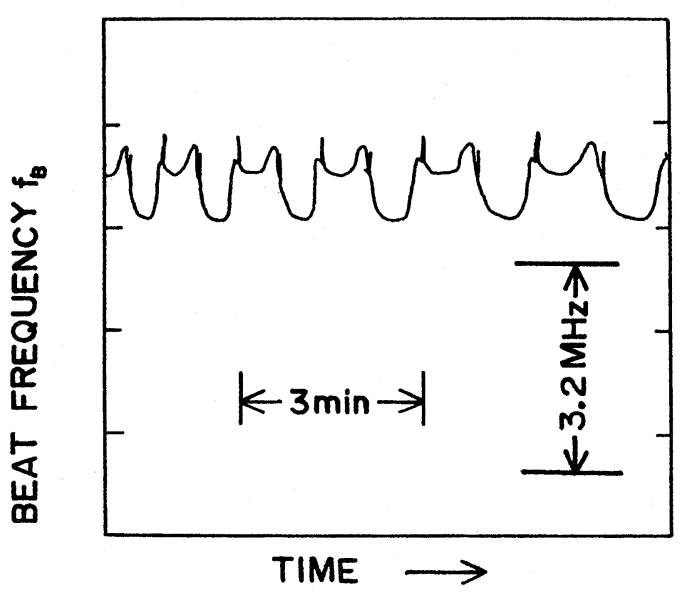

Fig. 5 Experimental results of axial-beat frequency as a function of time. 
アナライザーを使用し，実測した各軸モードの $\|, \perp$ 成分の相対的位置, 及び，その状態での モード間ビート周波数との関係をFig. 6に示す。 Fig. 6(b)は, Fig. 5 のビート周波数変化を拡大 したものである。図の状態Aは，2本の軸モー ドで発振しており，上，\|の順に軸モードが存 在する場合に, 軸モードビート周波数が最も低 い。 A， B，Cの状態の順に周波数が高くなり， 状態Cでは3本のモードが同時発振状態となる。 光スペクトルアナライザーによる観測結果, 及 びビート周波数変化から判断すると, $\|$ と土の 高周波数成分との間のビート周波数を測定して いると考えられる。3本の軸モード発振状態は,

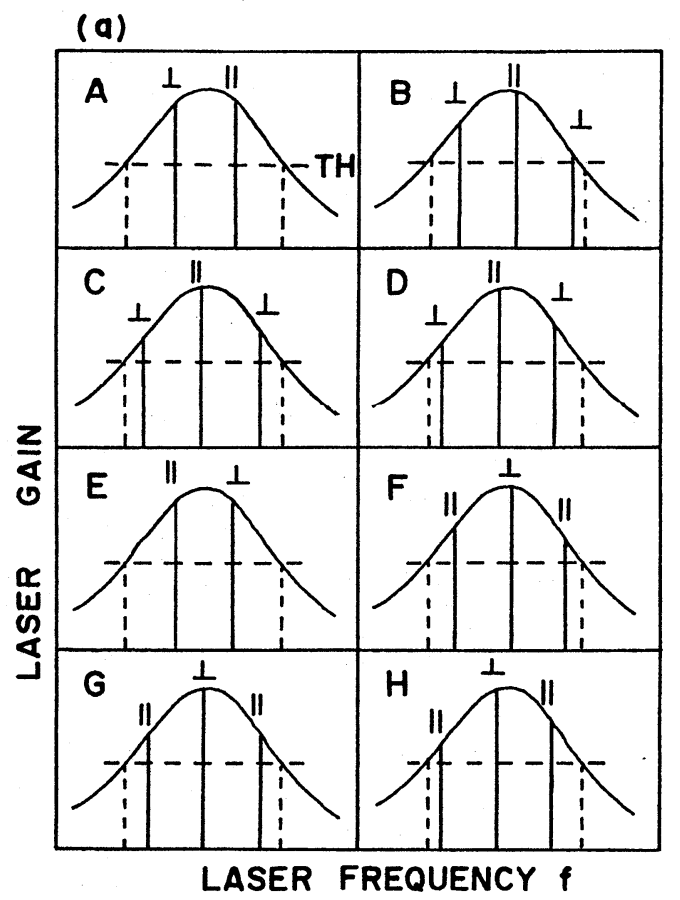

(b)

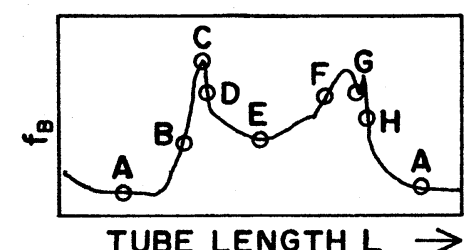

Fig. 6 Schematic diagram of (a) gain profile and axial modes, and (b) axial-beat frequency.
2本の軸モード発振状態に比較し軸モード間の 相互作用が強くなり，ビート周波数が高くなっ たものと考えられる。また，C，D，E状態の 順にビート周波数が低くなる。そして, 状態 $\mathrm{E}$ では2本の軸モード状態で発振し, 偏光状態は $\|, \perp の$ 順となる。この状態では，Aの状態に 比較し, ビート周波数が高くなっている。これ らの軸モード間のビート周波数の特性は, 各偏 光方向に対するレーザー共振器の $Q$ 值の違い, あるいは，屈折率の違いによるものと考えられ る。

安定化前のレーザーと他に準備した安定化レー ザーとのビート周波数をカウンタで計数した結 果をFig. 7に示す。カウンタの計数時間は，1秒 であった。ビート周波数は, レーザーの管長が 熱膨張に伴い, 変動する。また, この状態のア ラン分散を示した図がFig. 8である。安定化し ていない場合, レーザーの安定度は約 $10^{-6}$ であ ることが分かる。本研究において，軸モード間 のビート周波数をレーザーの安定化信号として 使用し，また加熱的にレーザー管の長さを制御 する場合，レーザー安定化に使用できる状態は Fig. 6(b)に㧍いてBとCの間及びFの位置が好ま しいが，予備的安定化実験の結果，F点におけ る制御がより安定であった。この結果は制御系 の安定性及びレーザー管の熱膨張速度に関係し

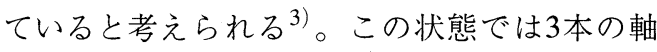
モードでレーザー発振しているが, $\|$ 偏光のモー ドのうち強度の弱い成分はビート周波数発生に

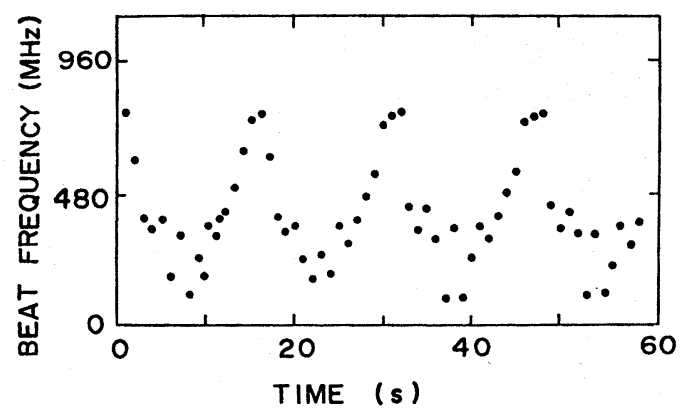

Fig. 7 Frequency fluctuations of the unstabilized laser as a function of time. 


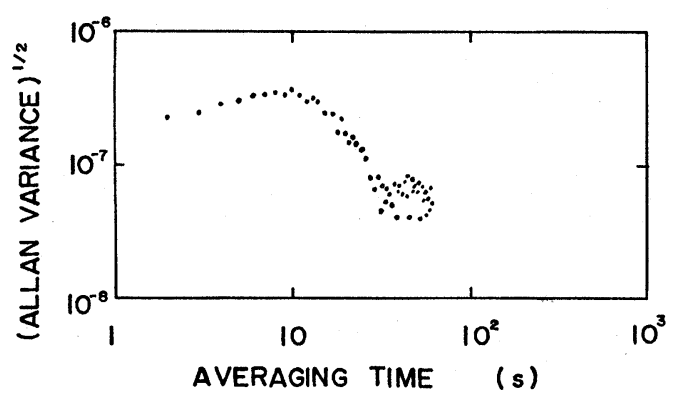

Fig. 8 Square-root of the normalized Allan variance vs. the averaging time $\tau$. The laser is at the free running state.

はほとんど寄与しないため，2本の軸モード間 ビート周波数が検出可能であった。

Fig. 9に安定化した場合のビート周波数変動 と時間との関係を示す。図に示すように安定化 が可能であった。安定化前のビート周波数の変 動幅は1.36 MHzであった。これに対し，安定 化後の変動幅は約 $0.04 \mathrm{MHz}$ となった。安定化 レーザーの周波数安定度を評価するため, 基準 レーザーとのビート周波数をカウンタで計数し, 計数データをパーソナル・コンピュータに入力 し解析した。計数時間は1秒で測定したビート 周波数と時間の関係をFig. 10に示す。Fig. 10 と Fig. 7とを比較すると明らかなように，安定化 されていることがわかる。図におけるビート周

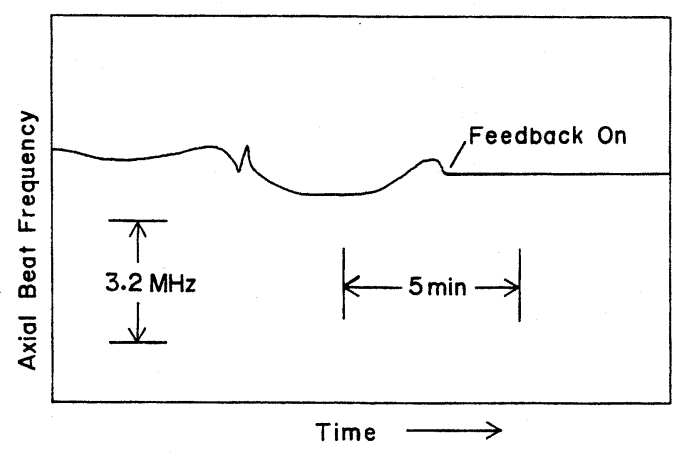

Fig. 9 Experimental result of frequency stabilization. The axial-beat frequency as a function of time.

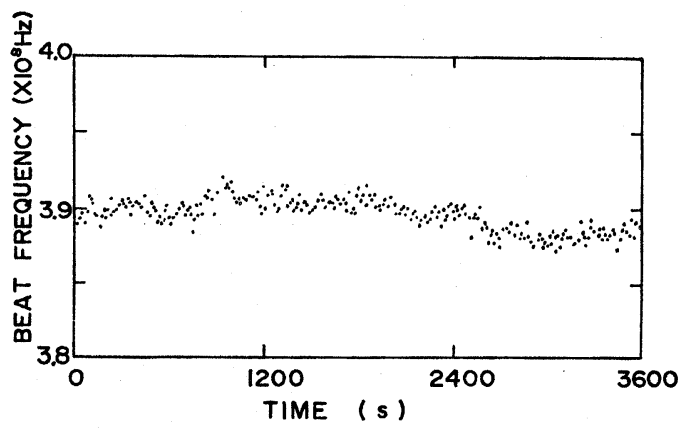

Fig. 10 Frequency fluctuations of the stabilized laser as a function of time.

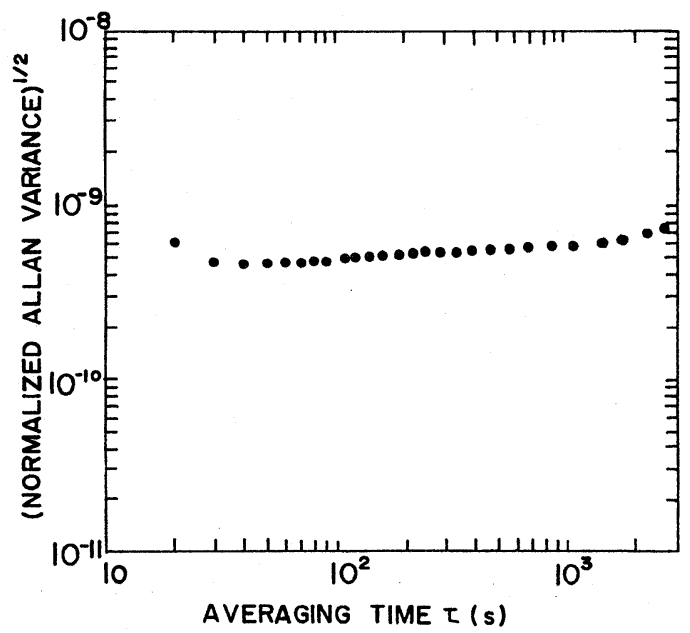

Fig. 11 Square-root of the normalized Allan variance vs. the averaging time $\tau$. The laser is at the stabilized state.

波数の変動幅は, $\pm 2.2 \mathrm{MHz}\left( \pm 4.6 \times 10^{-9}\right)$ で あった。ビート周波数変動のアラン分散をFig. 11 に示す。この結果, 周波数安定度は $4.5 \times 10^{-10}$ であることが分かる。また，安定化時のレーザー 出力の安定度は $0.21 \%$ であった。お, 安定化 された単一周波数は, Fig. 60Fから分かるよう に偏光子を使用すれば，得ることができる。

\section{5.まとめ}

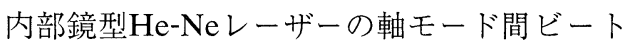
周波数はレーザー管の熱膨張とともに変動する 
が，この変動を積極的に利用した新しいレーザー 安定化法の詳細について述べた。本安定化法は, 軸モード間ビートと周波数シンセサイザーとの ビート周波数を用いて, レーザー周波数を制御 している。ビート周波数の最大変動幅は 1 秒の 平均時間において $2.2 \mathrm{MHz}\left(4.6 \times 10^{-9}\right)$ であり， アラン分散による周波数安定度は $4.5 \times 10^{-10}$ で あった。また, この場合のレーザー出力安定度 は0.21\%であった。この安定化レーザーは, 高 精度レーザー干渉計, 高周波ビート周波数を積 極的に利用した高速へテロダイン干渉計及びレー ザー距離計 ${ }^{17)}$ に使用可能であると考えられる。

本安定化法に抢いて, 軸モード間ビートと周 波数シンセサイザーの周波数がほぼ同一に設定 可能であるならば，DBMによって両周波数の 位相差を検出し, それによりレーザー周波数が 制御可能であると考えられる。この場合, FVC 回路を省略でき, さらなる高安定化が達成でき ると考えられる。

\section{謝 辞}

本研究にあたり種々ご協力いただいた深谷次 助氏，またご援助いただいた(株)ミットヨに感 謝いたします。

\section{参 考 文 献}

1) H. Matsumoto : Precision Eng. 6 (1984) 87.

2) A. Sasaki and S. Masuda : Appl. Opt. 30 (1991) 933.

3）佐々木, 石川：レーザー研究 11 (1983) 754.

4) R. Balhorn, H. Kunzmann and F. Lebowsky : Appl. Opt. 11 (1972) 742.

5) N. Umeda, M. Tsukiji and H. Takasaki : Appl. Opt. 19 (1980) 442.

6) C. Eom, T. B. Eom and M. S. Chung : Appl. Phys. Lett. 57 (1990) 739.

7) P. -Y. Chien and C. -L. Pan : Rev. Sci. Instrum. 62 (1991) 933.

8）梅田: 光学 16 (1987) 398.

9) 田中, 大田, 一ノ瀬, 村上:レーザー研究 20 (1992) 392.

10) A. Sasaki, T. Okada, S. Kawai and H. Aoyama : Appl. Phys. Lett. 58 (1992) 1151.

11) T. Yoshino : Jpn. J. Appl. Phys. 11 (1972) 263.

12) R. Balhorn, F. Lebowsky and D. Ullrich : Appl. Opt. 14 (1975) 2955.

13) A. Sasaki : Jpn. J. Appl. Phys. 24 (1985) 885.

14) W. R. C. Rowley : Meas. Sci. Technol. 1 (1990) 348.

15）上田: 光アライアンス 2(3) (1991) 9.

16) D. W. Allan : Proc. IEEE 54 (1966) 221.

17) K. Seta and T. O'ishi : Appl. Opt. 29 (1990) 354. 